\title{
Nucleic Acid Strand
}

National Cancer Institute

\section{Source}

National Cancer Institute. Nucleic Acid Strand. NCI Thesaurus. Code C45831.

A single chain of nucleotides. 